\title{
Advantages and Disadvantages of Using e-Learning in University Education: Analyzing Students' Perspectives
}

\author{
Alaa Zuhir Al Rawashdeh ${ }^{1,2}$, Enaam Youssef Mohammed ${ }^{1,3}$, Asma Rebhi Al Arab ${ }^{1}$, \\ Mahmoud Alara ${ }^{4}$ and Butheyna Al-Rawashdeh ${ }^{2}$ \\ ${ }^{1}$ Ajman University, Ajman, UAE \\ ${ }^{2}$ Al Balqaa Applied University, Jordan \\ ${ }^{3}$ Ain-Shams University, Egypt \\ ${ }^{4}$ Clemson University, USA \\ alaa rwashdeh@yahoo.com \\ Judy3021@gmail.com \\ asma arab74@yahoo.com \\ malarab@clemson.edu \\ Butheynar@bau.edu.jo
}

Abstract: The architecture of a learning system implies a heavy task for e-learning to be integrated into a complicated system that is flexible, time scalable, and capable of lasting, even though there are many diverse tools. Currently, higher education in United Arab Emirates is experiencing a major transformation, considering increased accessibility. Therefore, the study aims to identify the advantages and disadvantages of e-learning in university education in United Arab Emirates. A descriptive study design was used to randomly select students from Ajman university, who were enrolled in 2018/2019 academic year. A close-ended structured questionnaire was constructed to collect data from students. Frequencies and percentages were used to analyse the data collected. $81 \%$ students stated that e-learning provides scientific material in an interesting way. Similarly, $80 \%$ students have responded that e-learning increases the possibility of contact between students among themselves and between the students and the teacher. $73 \%$ students indicated that due to increasing social isolation, they spend more time in front of the technical means of social interaction account and face-to-face with others. $70 \%$ students have indicated that there is a presence of electronic illiteracy among parents, which reduces their ability to follow their children electronically. It is essential for potential e-learners to understand the differences between an e-learning classroom setting and a conventional classroom setting as there are both advantages and disadvantages of elearning to both environments that can probably influence their overall performance as a student.

Keywords: Advantages, Disadvantages, E-learning, University Education

\section{Introduction}

Electronic learning or e-learning is used to offer instructional programs to distant learners (Arkorful and Abaidoo, 2015). It is an online learning platform that emerges in a formal context and utilizes a variety of multimedia technologies. Electronic hardware and software support this system either offline or online. A personal computer is usually used for delivering training or computer-enhanced learning related to e-learning (Samsuri, Nadzri and Rom, 2014). Other communication technologies deliver learning based on tutorials, learning support systems, and online lectures (Kattoua, Al-Lozi and Alrowwad, 2016). It is based on technology for improving classroom engagement through positive environment, where students are deliberately engaged in online tutorials for completing a task assigned to them.

E-learning ensures that students are completely involved as learning takes place together with texts, videos, sounds, collaborative sharing, and interactive graphics. It may enhance the quality of teaching and learning, report the need for higher institutions for maintaining competitive advantage, and access to education and training in this globalizing marketplace for students (Islam, Beer and Slack, 2015). The integration of information technology (IT) in the form of e-learning has resulted in the reduction of students cost while improving the quality of learning and teaching (Songkram, 2015). This shows that e-learning can be economical for students using it, and they can perform other useful activities in their spare time (Aparicio, Bacao and Oliveira, 2016).

Flexibility is another major advantage of e-learning as it provides learners the benefit to take classes anywhere and anytime. Furthermore, e-learning cater different types and varieties of learning approaches by utilizing much interactive content available on the internet (Songkram et al., 2015). The accessibility of technology and 
wide nature of the internet have generated a surge in the need for web-based learning and teaching. Distance learning is an increasingly expanding environment, which enable users the flexibility to operate outside the barriers of place and time. In university education, online learning is explained as learning that takes place completely or partially over the internet (Gilbert, 2015). Online learning is beneficial to a number of learners and appears as more common in settings from elementary schools to high schools and into post-secondary education.

The role of engagement in e-learning is important for effective learning as it is not merely student-student interaction that matters. There are six different forms of engagement that can be identified in distance learning education: (1) teacher-content (2) content-content (3) student-teacher (4) student-student (5) teacher-teacher and (6) student-content (Talebian, Mohammadi and Rezvanfar, 2014). Theories that encourage adoption of new technologies in the learning process are based on the postulation that students are active participants who pursue and create knowledge throughout a meaningful context. Different means of collaborative tools can be used for communication and collaborative learning (Sarkar, 2012). The architecture of a learning system implies a heavy task for e-learning to be integrated into a complicated system that is flexible, time scalable, and capable of lasting, even though there are many diverse tools. The learning space is left under the control of the instructors and institutions using conventional learning management system (LMS) irrespective of any external tools (Sarrab, Al-Shihi and Rehman, 2013). In particular, this leaves minimal space for learners to organize their digital learning space and to carry-forward their activities.

Currently, higher education in United Arab Emirates is experiencing a major transformation, considering increased accessibility. Knowledge is being created and implemented to the higher education setting with innovative ways to obtain and share information and changes in technology at a rapid rate. Educational institutions are providing online classes or courses using online elements and a face-to-face course delivery. Universities deliver almost all courses using web-based technology to facilitate course contents' delivery, assessments, and assignments. Therefore, it becomes essential for understanding the advantages and disadvantages as perceived by the learners and further act upon the enhancement areas for a successful integration of online learning, based on the increasing importance of online learning programs. Hence, the study aims to identify the advantages and disadvantages of e-learning in university education in United Arab Emirates (UAE). The study further highlights the barreirs that students face in the use of e-learning, which are outlined in the form of disadvantages highlighted by students through their responses. Considering the study aim, following questions will be answered in this study.

1. What are some advantages and disadvantages of using e-learning when implemented in the university education?

2. What are some major barreirs identified by students in the e-learning?

\section{Literature Review}

Sociocultural theory and constructivism are beneficial to explain the use of social networks in online learning, collaborative learning, and importance of social integration in online social learning environments. Lev Vygotsky (1987) has explained that children learn effectively in a social environment, and create meaning using engagement with others. A child is able to perform and solve more complicated tasks that he/she can autonomously with direction, support, and collaboration. Students can actively participate in the learning process, if the classes are managed to support learning using discovery. This type of learning offer students to inductively and independently provide conclusions, lead to the development of intellectual abilities, and increase the quality of durability and knowledge.

\subsection{Advantages of E-learning}

The implementation of e-learning in education has been favourable in multiple contexts. Previous studies, have presented several advantages associated by the implementation of e-learning technologies into university education (Raspopovic et al., 2017). E-learning has been viewed as the ability to focus on the requirements of individual learners. For instance, focusing on the needs of individual learners can deliver knowledge in digital age effectively as compared to educational institutions' needs or instructors (Huang and Chiu, 2015). Objectives can be achieved in the shortest time with least efforts through e-learning. When managing the e-learning environment, its effect on educational learning are observed in providing equal access to the information regardless of the users' locations, their ethnic origins, races, and ages. The environment for 
e-learning also help students or learners to rely on themselves so that instructors are no longer the solitary knowledge source rather they serve as guides and advisors (Joshua et al., 2016).

Several studies have shown the positive effects of e-learning from the insights of learners or students (Gautam and Tiwari, 2016; Martínez-Caro, Cegarra-Navarro and Cepeda-Carrión, 2015; Chang, 2016). For instance; elearning allows to observe much flexible learning ways to go for classes with much reduced need for travel. Learners are allowed to get deeper insights of the information through activities that are carried-out in the classroom through interactive video facility (Gautam and Tiwari, 2016; Martínez-Caro, Cegarra-Navarro and Cepeda-Carrión, 2015). This allow learners to respond promptly toward the activities.

It is important for instructors to embrace the advanced technology throughout the process of teaching and; therefore, learning has a range of skills in information and communication technology (ICT) (Aithal and Aithal, 2016). It is also observed that e-learning systems allow enhanced communication between students, and instructors. Part time and full-time students can actively participate in the online degree courses selected from any location or place, providing people who are traveling or relocated, an easily accessible resource for experience and learning (Radu, Radu and Croitoru, 2015). The integration and use of e-learning offers disabled people an opportunity for advancing their education from any location. Four common types of e-learning systems have been developed which includes; Learning Content Management System (LCMS), Learning Support System (LSS), Learning Design System (LDS), and Learning Management System (LMS) (Adzharuddin and Ling, 2013). Although all the system has a similar name, however, the function of each system is different. In the process of e-learning, LMS has been widely used by various education institutions. It is further regarded as a platform that is used to manage user's experience while interacting with e-learning content. LMS in general perform three common functions, which include; presenting and systematizing training content, create assignments to test and solidify knowledge, to evaluate progress (Rietsema, 2016). The LMS software is further used to publish, plan, deliver, and place self placed online courses. Muruthy \& Yamin (2017) in their study examined how LMS is effective for students enrolled in higher education institutions, along with their usage in the learning process. A number of advantages were outlined in this study. First include flexibility, as the use of LMS resulted in increased collaboration between faculty and students. It is further effective in enhancing the institutional practices which requires learner's involvement. LMS is also effective in promoting centralized learning, easy upgrades, simplified learning process, low cost, centralized learning etc (Muruthy \& Yamin, 2017).

Other important benefits as highlighted by Al-Handhali, Al-Rasbi, \& Sherimon (2020) indicated several benefits of LMS, making it user friendly, effective in managing time, provide ease in the management of courses, teachers, facilities, generate reports. It further provides timely reminder to users which include; date of deliveries, answering questions, test dates etc. Aydin \& Tirkes (2010) in their study analyzed the usefulness of LMS and Moodle. Findings of the study indicated that Moodle, undoubtedly is one of the effective tools of LMS. Some of the identified advantages include its flexibility following the modules employed and help in any in teaching through any style or environment mode. Considering the modular design and its user interface, Moodle's superior rate of usability along with its competitors. However, considering the learning environment Moodle has been recognized as easy to use due to variety of options available. Besides, increase in the user authentication options, easy installation process along with the maintenance in Moodle helps in increasing the frequency of usage (Aydin \& Tirkes, 2010).

\subsection{Disadvantages of E-learning}

Despite of the significant advantages of e-learning, students encounter several challenges which ultimately lead towards either limited or negative outcomes. Such as; Arkorful and Abaidoo (2015) in their study outlined that e-learning, in certain cases is held through remoteness and contemplation resulting in lack of student's interaction. In comparison with the contemporary mode of education, e-learning might result in being less effective due to the absence of face to face encounter with instructions or teachers. Since in e-learning method, assessments are generally held online which reduces the possibility of restricting illegitimate activities such as; cheating, plagiarism etc (Arkorful and Abaidoo, 2015). The absence of essential personal interactions is the most noticeable drawback of e-learning, not only among colleague learners, but also between instructors and learners (Islam, Beer and Slack, 2015). There is a scarcity of community in the online learning environment as student-student engagement is much less of a concern when compared with studentinstructor interaction. Gilbert (2015) highlighted that most of the students wish to work autonomously to avoid the need to interact with their classmates. Cultural barrier is another important disadvantage of 
introducing an online course. Aparicio, Bacao and Oliveira, (2016) in their study evaluated the influence of cultural characteristics which includes individualism and collectivism in determining the perceived success of elearning. Findings of the study indicated a significant influence of individualism and collectivism on organizational and individual impacts.

Technology is a platform that can be easily acquired for granted when it is engaged into daily life, but it is not widely used because of the lack of monetary benefits for achieving access. The global knowledge available on the internet is led by increasing the proportion of computers and other electronic devices to students (Talebian, Mohammadi and Rezvanfar, 2014). Another disadvantage is maintaining motivation in an online course that online learners experience. Students who lack self-motivation and independence had reduced success rates as compared to their counterparts (Sarkar, 2012). Learners that lack self-regulation have a tendency to not assign sufficient time for completing assignments; therefore, switching in poor quality work or late assignments. Overall, successful students have stronger beliefs that they will succeed, better technology skills and access, higher self-responsibility, and higher self-organization skills (Sarrab, Al-Shihi and Rehman, 2013). Students must be able to assess the motivating factors to continue the momentum throughout the duration of the course. Students lack motivation and can easily lose sight of their original objective, rapidly become lost within the course, and consequently withdraw from the course (Raspopovic et al., 2017). Therefore, it is pertinent to determine the success of an individual to undertake an online course by understanding learning styles and self-behaviour.

\section{Material and Methods}

\subsection{Study Design and Setting}

A cross sectional study design is adopted to identify the advantages and disadvantages of e-learning in university education. Higher education institutes were focused in this study while UAE was targeted as preferred study setting.

\subsection{Population and Sampling}

University students in UAE have been considered as population for this study and; thus, students enrolled in Ajman University in the second semester of the academic year 2018-2019 were considered as study population. Students in other semesters and academic years were excluded from the inclusion criteria. None of the faculty staff was considered as a part of this study. Based on the sample size calculation and number of students studying in second semester, 100 students were randomly selected as a sample for this study, with an equal male and female ratio.

\subsection{Procedure}

Prior to the data collection, a permission was acquired from the academic's director of Ajman university and the nature and objective of the study was explained in a formal arranged meeting. After obtaining permission and ethical approval from Ajman University ethical committee, consent forms were signed from students who wish to participate in the study. All the students were ensured that their participation and personal information will be kept confidential. A close-ended structured questionnaire was constructed to collect data from students.

\subsection{Instrument}

The questionnaire comprised of two sections; first section presents information about age, gender, department, program, place of residence, nationality, and social status. Second part was further subdivided into two sections; (1) advantages, and (2) disadvantages of e-learning. 18 items comprised in the first subsection and 16 items comprised in the second sub-section.

\subsection{Reliability and Validity}

The questionnaire was evaluated from experts in the sociological department of Ajman University before using it for data collection. Corrections were made in the questionnaire, considering the suggestions of experts to ensure its validity. On the other hand, Cronbach alpha was used to measure the reliability of the questionnaire items. In this regard, 15 students were included in the pilot study to check the reliability of the questionnaire. The participants included in the pilot study were excluded from the final sample. After performing pilot study, Cronbach alpha confirmed the reliability of the study as its coefficient exceeds the standard benchmark of $70 \%$ to show high reliability of the questionnaire items. 


\subsection{Data Analysis}

Data collected were analysed using frequencies and percentages as part of descriptive statistics through statistical package for social sciences (SPSS) version 20.0.

\section{Results}

Table 1 shows demographic characteristics. The findings show an equal proportion of students ( $50 \%$ male and $50 \%$ female). Most of the study sample was in the age group $20-22$ years (43\%), $24 \%$ in the age group of $23-25$ years, $15 \%$ in the age group of $17-19$ years while $8 \%$ in the age group of $26-28$ years.

Table 1: Demographics

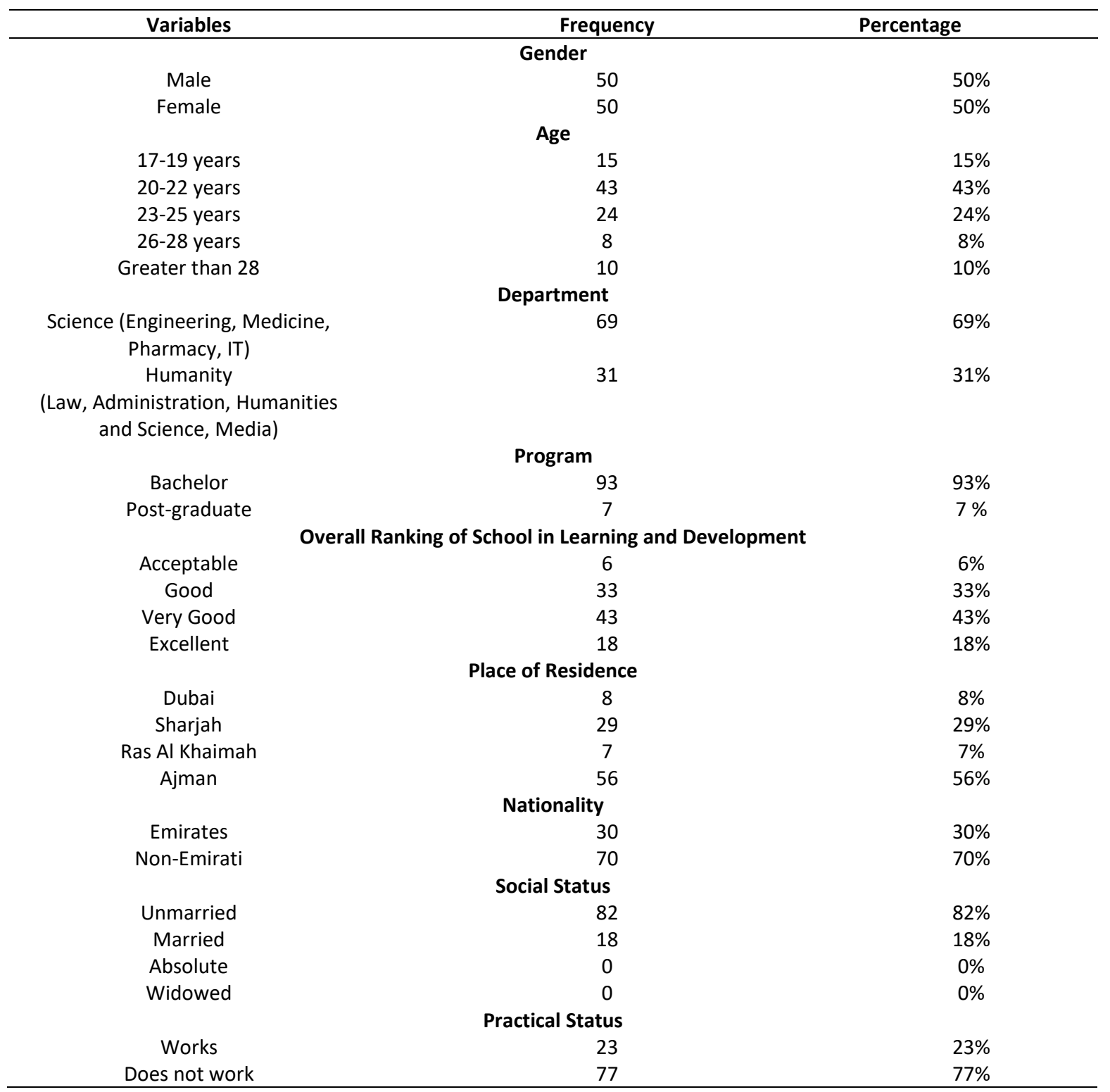

Findings in Table 2 of the study show that the majority of the study members agree that there are positives to the use of e-learning. $81 \%$ students have stated that e-learning provides scientific material in an interesting way. Similarly, $80 \%$ students have responded that e-learning increases the possibility of communication and interaction between students and with teacher. Furthermore, 78\% students indicate that e-learning enable students to communicate with the teacher by e-mail at any time and any place and provides the subject throughout the day and all days of the week. 
Table 2: Advantages of E-learning

\begin{tabular}{|c|c|c|c|c|}
\hline Rank & Items & Agree \% & Somewhat agree \% & Not agree $\%$ \\
\hline 4 & $\begin{array}{l}\text { The use of computers } \\
\text { raises the level of } \\
\text { students' culture and } \\
\text { skills }\end{array}$ & 77 & 16 & 7 \\
\hline 1 & $\begin{array}{l}\text { Provides scientific } \\
\text { material in an } \\
\text { interesting way }\end{array}$ & 81 & 15 & 4 \\
\hline 8 & $\begin{array}{l}\text { Help students in } \\
\text { retaining information } \\
\text { for long periods. } \\
\text { Provides immediate and } \\
\text { continuous feedback to } \\
\text { the learner }\end{array}$ & 71 & 21 & 8 \\
\hline 6 & $\begin{array}{l}\text { Increases the learner's } \\
\text { motivation to learn }\end{array}$ & 75 & 20 & 5 \\
\hline 7 & $\begin{array}{l}\text { Encourage students to } \\
\text { participate rather than } \\
\text { listen }\end{array}$ & 72 & 21 & 7 \\
\hline 10 & $\begin{array}{l}\text { Raise the level of } \\
\text { students' achievement } \\
\text { of the scientific subject }\end{array}$ & 68 & 19 & 13 \\
\hline 7 & $\begin{array}{l}\text { Helps increase student- } \\
\text { teacher interaction }\end{array}$ & 72 & 20 & 8 \\
\hline 10 & $\begin{array}{l}\text { Helps in increasing } \\
\text { student-teacher } \\
\text { interaction }\end{array}$ & 68 & 20 & 12 \\
\hline 11 & $\begin{array}{l}\text { Increases students' } \\
\text { capacity of learning }\end{array}$ & 66 & 22 & 12 \\
\hline 9 & Enriches the curriculum & 69 & 17 & 14 \\
\hline 5 & $\begin{array}{l}\text { Students can self-learn } \\
\text { through digital vessels } \\
\text { such as CDs or the } \\
\text { internet }\end{array}$ & 76 & 16 & 8 \\
\hline 3 & $\begin{array}{l}\text { Students can } \\
\text { communicate with the } \\
\text { teacher by e-mail } \\
\text { anytime and anywhere. }\end{array}$ & 78 & 13 & 9 \\
\hline 12 & $\begin{array}{l}\text { Helps family } \\
\text { communicate with the } \\
\text { university to follow and } \\
\text { guide their children }\end{array}$ & 63 & 20 & 17 \\
\hline 13 & $\begin{array}{l}\text { Take into account } \\
\text { individual differences } \\
\text { between students' } \\
\text { levels. }\end{array}$ & 57 & 28 & 15 \\
\hline 9 & Helps minimize tutoring. & 69 & 16 & 15 \\
\hline 4 & $\begin{array}{l}\text { Reduces administrative } \\
\text { burdens for university } \\
\text { and faculty member }\end{array}$ & 77 & 14 & 9 \\
\hline 3 & $\begin{array}{l}\text { The course is } \\
\text { available } 7 / 24\end{array}$ & 78 & 15 & 7 \\
\hline 2 & $\begin{array}{l}\text { Increase the possibility } \\
\text { of communication } \\
\text { between students } \\
\text { among themselves and } \\
\text { between students and } \\
\text { teachers }\end{array}$ & 80 & 16 & 4 \\
\hline
\end{tabular}

Table 3 shows that the study members agree that there are drawbacks to the use of e-learning at Ajman University. $73 \%$ students indicate that due to increasing social isolation, they spend more time in front of the 
technical means of social interaction account and face-to-face with others. $70 \%$ students have indicated that there is a presence of electronic illiteracy among parents, which reduces their ability to follow their children electronically. $68 \%$ students have revealed that the application of e-learning needs to a certain extent of qualified users to deal with technological developments used in this type of education.

Table 3: Disadvantages of E-learning

\begin{tabular}{|c|c|c|c|c|}
\hline Rank & Items & Agree \% & Somewhat agree \% & Not agree \% \\
\hline 2 & $\begin{array}{l}\text { The presence of } \\
\text { electronic illiteracy } \\
\text { among parents reduces } \\
\text { their ability to follow } \\
\text { their children } \\
\text { electronically }\end{array}$ & 70 & 18 & 21 \\
\hline 4 & $\begin{array}{l}\text { Effectively affects } \\
\text { students (radiation, } \\
\text { electromagnetic field, } \\
\text { obesity, etc). }\end{array}$ & 66 & 25 & 9 \\
\hline 4 & $\begin{array}{l}\text { Hinder technical failures } \\
\text { in educational scientific } \\
\text { devices }\end{array}$ & 66 & 25 & 9 \\
\hline 1 & $\begin{array}{l}\text { Increases students' } \\
\text { social isolation (spends } \\
\text { longer time in front of } \\
\text { technology at the } \\
\text { expense of social } \\
\text { interaction face to face } \\
\text { with others) }\end{array}$ & 73 & 17 & 10 \\
\hline 8 & $\begin{array}{l}\text { Difficulty in providing } \\
\text { extracurricular } \\
\text { classroom activity } \\
\text { classes }\end{array}$ & 59 & 24 & 17 \\
\hline 9 & $\begin{array}{l}\text { Difficulty applying } \\
\text { calendar methods and } \\
\text { tools. }\end{array}$ & 58 & 22 & 20 \\
\hline 5 & $\begin{array}{l}\text { Students focus on } \\
\text { technology without } \\
\text { paying attention to } \\
\text { scientific content, which } \\
\text { reduces their } \\
\text { understanding }\end{array}$ & 64 & 18 & 18 \\
\hline 12 & $\begin{array}{l}\text { Increases students' } \\
\text { burdens and } \\
\text { responsibilities }\end{array}$ & 50 & 28 & 22 \\
\hline 11 & $\begin{array}{l}\text { Increases the } \\
\text { phenomenon of } \\
\text { cheating in tests }\end{array}$ & 51 & 22 & 27 \\
\hline 10 & $\begin{array}{l}\text { Limit the role of the } \\
\text { teacher in guiding } \\
\text { students, which affects } \\
\text { their behaviour and } \\
\text { ethics }\end{array}$ & 57 & 23 & 20 \\
\hline 8 & $\begin{array}{l}\text { The greater focus of e- } \\
\text { learning on the } \\
\text { cognitive side rather } \\
\text { than the skill and } \\
\text { emotional side }\end{array}$ & 59 & 27 & 14 \\
\hline 3 & $\begin{array}{l}\text { The application of e- } \\
\text { learning needs a certain } \\
\text { type of qualified users } \\
\text { to deal with the } \\
\text { technological } \\
\text { developments used in }\end{array}$ & 68 & 24 & 8 \\
\hline
\end{tabular}


The Electronic Journal of e-Learning Volume 19 Issue 32021

\begin{tabular}{|c|c|c|c|c|}
\hline Rank & Items & Agree \% & Somewhat agree \% & Not agree \% \\
\hline & this type of education & & & \\
\hline 7 & $\begin{array}{l}\text { The cost of e-learning, } \\
\text { especially in the initial } \\
\text { stages of its application }\end{array}$ & 60 & 28 & 12 \\
\hline 6 & $\begin{array}{l}\text { E-learning lacks the } \\
\text { presence of humanity } \\
\text { between teachers and } \\
\text { students }\end{array}$ & 61 & 21 & 18 \\
\hline 7 & $\begin{array}{l}\text { Another person can play } \\
\text { the intended role of the } \\
\text { learner in the learning } \\
\text { process }\end{array}$ & 60 & 26 & 14 \\
\hline 7 & $\begin{array}{l}\text { E-learning does not } \\
\text { focus on all senses, but } \\
\text { on the senses of hearing } \\
\text { and vision only without } \\
\text { the rest of the senses }\end{array}$ & 60 & 19 & 21 \\
\hline 2 & $\begin{array}{l}\text { The presence of } \\
\text { electronic illiteracy } \\
\text { among parents reduces } \\
\text { their ability to follow } \\
\text { their children } \\
\text { electronically }\end{array}$ & 70 & 18 & 21 \\
\hline 4 & $\begin{array}{l}\text { Effectively affects } \\
\text { students (radiation, } \\
\text { electromagnetic field, } \\
\text { obesity, etc) }\end{array}$ & 66 & 25 & 9 \\
\hline
\end{tabular}

Table 4: Other Advantages and Disadvantages

\begin{tabular}{|c|c|c|}
\hline & Advantages & Disadvantages \\
\hline 1 & Easy to communicate & Difficulty for the beginner \\
\hline 2 & Develop individual skills & $\begin{array}{l}\text { Lack of availability at times and } \\
\text { It needs more time }\end{array}$ \\
\hline 3 & Increase students' skill in education & $\begin{array}{l}\text { Addiction using electronics and } \\
\text { dependence }\end{array}$ \\
\hline 4 & Our cartons provide heavy book carry & $\begin{array}{l}\text { When using electronics, we don't } \\
\text { seem to be studying for parents and } \\
\text { they think we're playing and wasting } \\
\text { time }\end{array}$ \\
\hline 5 & $\begin{array}{l}\text { Opening the field to increase the level } \\
\text { of education / culture in general and } \\
\text { development by taking courses } \\
\text { through the Internet and dialogue } \\
\text { sessions and participation in } \\
\text { discussions there are those who ask } \\
\text { students to participate in a voice and } \\
\text { this limits all the negatives } \\
\text { mentioned above }\end{array}$ & $\begin{array}{l}\text { It is according to the teacher or the } \\
\text { recipient of the scientific material and } \\
\text { his ability to communicate } \\
\text { information and respond to his } \\
\text { students and seized and enforce } \\
\text { respect }\end{array}$ \\
\hline 6 & $\begin{array}{l}\text { Helping students among themselves, } \\
\text { especially at the time of the exam }\end{array}$ & $\begin{array}{l}\text { Reduces teachers' interest in the } \\
\text { material }\end{array}$ \\
\hline 7 & $\begin{array}{l}\text { Facilitate study and communication } \\
\text { with teachers in all comfort }\end{array}$ & $\begin{array}{l}\text { Upgrading of devices is possible to } \\
\text { lead to delay in dealing }\end{array}$ \\
\hline 8 & $\begin{array}{l}\text { Teach the learner and the teacher } \\
\text { with ease with each other at any time }\end{array}$ & $\begin{array}{l}\text { The material is defined in a particular } \\
\text { framework and the difficulty of } \\
\text { absorption because of the same way } \\
\text { reading from PowerPoint, for } \\
\text { example, this becomes a very boring } \\
\text { routine unlike the explanation } \\
\text { without electronic devices is better } \\
\text { and education is in a wide range and } \\
\text { discussions }\end{array}$ \\
\hline
\end{tabular}




\begin{tabular}{|c|c|c|}
\hline & Advantages & Disadvantages \\
\hline 9 & & $\begin{array}{l}\text { You cannot be called for recording his } \\
\text { pen and needs to buy sophisticated } \\
\text { tools expensive price to enable it to } \\
\text { reverse the paper book, which only } \\
\text { needs a pen to record notes }\end{array}$ \\
\hline
\end{tabular}

\section{Discussion}

Students are progressively achieving access to the far-reaching environment of online learning, specifically in the university setting. The strategy to increase technology in university setting across the UAE has consequently driven to an increasing accessibility for students to online courses in a range of subjects. The competitive atmosphere of university entry is another potential factor that has contributed to the increase of online courses being offered at the university setting. Students are taking university level courses for maintaining a competitive edge. Many of the university level courses offered to students are in an online setting. Therefore, the study has identified the advantages and disadvantages of e-learning in supporting elearners to become successful students using interactive online platforms.

Findings revealed that there were commonalities among the students' response, which links to common attributes of effective learners while each student is unique in their approach to online learning. It is observed that perceptions of students toward the advantages and disadvantages of the e-learning in university education. The findings have emphasized the aspects of the e-learning courses that potential online learners should take into account when realizing their individual preference. Based on these findings, it is essential for potential e-learners to understand the differences between an e-learning classroom setting and a conventional classroom setting as there are both advantages and disadvantages of e-learning to both environments that can probably influence their overall performance as a student (Rashid et al., 2016).

These findings have been supported through previous studies where a wide range of learning styles is one of the advantages of e-learning to students (Rusu and Tudose, 2018; Raspopovic, Cvetanovic and Jankulovic, 2016). Students also prefer what they like and e-learning allows them to prefer subjects they like and enjoy. It is also identified that students are independent to select the types of e-learning tools they preferred to use. In a number of cases, CD-ROM and internet are used as their main e-learning tools. This occurs because mostly students can get easy access to the Internet as they have the connection at home (Chang, 2016). Similarly, it has been found that a wide-range of multimedia inputs allow learners to seek knowledge that would associate to their personal and prior experiences, and involve them in interdisciplinary training.

E-learning can be a potential platform in providing a number of delivery methods for different types of learners, when compared to conventional classrooms. Furthermore, e-learning is an influential tool as it can provide unique learning styles and improve academic performances of students. Students can actively participate in e-learning environment where they can increase their thinking ability and learn independently (Dumford and Miller, 2018). Students can have systematic lessons as it provides content and exercises portrayed in animations, sounds, and videos.

Among the students, the lack of face-to-face interaction in their studies was the major disadvantage of elearning, while collaborative learning among peers is essential for the students as they improve their knowledge and exchange ideas. Students by nature are social learners who often prefer to learn and interact with their peers in groups. The tendency to surf social web extensively such as Twitter and Facebook, download games, and watch movies on YouTube was considered as another disadvantage of e-learning to students. It has been observed that social web excessively can affect the brain to shrink and the condition may lead to decline in concentration.

Alghizzawi et al. (2019) identified some of the major advantages of e-learning, as it delivers education in the virtual environment by the inclusion of different devices which include; mobile phones, personal computers, and tablets (Salloum \& Al-Emran, 2018; Salloum et al. 2019). This virtual learning method help teachers and students in providing access to course contents in digital form, share knowledge, while making learning more effective with increased interaction among teachers and learners through online forums, knowledge and content sharing. These platforms stimulate learning through different features which includes, development of online courses, evaluation and monitoring of activities for students and teachers (Alghizzawi et al., 2019). 
Araújo Júnior and Marquesi (2009) further added that e-learning methods such as LMS help in enabling a synchronized communication, by promoting the use of different strategies while promoting a dialogue and students' active participation. In relation to the assessment methods employed in e-learning systems, Rahrouh, Taleb \& Mohamed (2018) added that LMS in general has been effective, usable, efficient, manageable, and reliable. The respondents further showed a positive attitude towards the use of LMS and its effectiveness in students' assessment. While, Yilmaz (2017) identified some of the commonly used techniques in the online assessment of students in virtual learning. According to the study, the commonly used methods include; multiple choice questions, open ended questions, short answer questions, true and false statements related exercises. The researchers further examined that online exams include assignments. Upon examining the lecturer's opinion and alternative techniques of students' performance assessment, it was observed that majority of the lecturer's follow latest developed trends in evaluation and assessment of student's performance. In addition, the respondents further favoured the use of student-centered evaluation techniques (Yilmaz, 2017).

\section{Conclusion}

E-learning is an effective tool to transfer knowledge and it has the potential for overtaking the conventional teaching method. E-learning training help learners and instructors in educational environment. Students' needs are becoming priority for instructors and; thus, universities and colleges are implementing e-learning system in their own training programs. Through the study findings, it has been identified that e-learning has been advantageous to its users in many ways. One of the most dominant characteristics of e-learning is that it ensures ease of communication between teachers and students, and contributes in developing students' skills. It further contributes in providing scientific material to students in an interesting manner. In contrast to this, elearner has developed negative influence on students as it promotes social isolation due to increase in screen time.

The study has concluded that students prefer to use e-learning since it provides chances to enhance their learning and increase their abilities. On the contrary, the support of e-learning is not adequate for assuring the advantages for effective learning students to socially interact with their fellowship and mentors during their academic year. In particular, there is an actual need for a well-established e-learning environment, which learners and instructors can rely on. E-learning will become more popular to make the users feel secure and comfortable with the complement of instructors and mentors. Future studies are required on a larger scale, including additional online courses, professors, and students to better assess the advantages, disadvantages, and useful strategies of successful students.

\section{Acknowledgement}

The authors are very thankful to all the associated personnel in any reference that contributed in/for the purpose of this research. Further, this research holds no conflict of interest and is not funded through any source.

\section{References}

Aithal, P. S., and Aithal, S., 2016. Impact of on-line education on higher education system. International Journal of Engineering Research and Modern Education (IJERME), 1(1), pp. 225-235.

Alghizzawi, M., Habes, M., Salloum, S. A., Abd, M., Ghani, C. M., and Shaalan, K., 2019. The effect of social media usage on students'e-learning acceptance in higher education: a case study from the United Arab Emirates. International Journal of Information Technology, 3(3), 13-26.

Al-Handhali B. A., Al-Rasbi A. T., and Sherimon P. C., 2020. Advantages and disadvantages of earning Management System (LMS) at AOU Oman. International Journal of Technology, 1(2), 222-228.

Aparicio, M., Bacao, F., and Oliveira, T., 2016. Cultural impacts on e-learning systems' success. The Internet and Higher Education, 31, pp. 58-70.

Arkorful, V., and Abaidoo, N., 2015. The role of e-learning, advantages and disadvantages of its adoption in higher education. International Journal of Instructional Technology and Distance Learning, 12(1), pp. 29-42.

Aydin, C. C., \& Tirkes, G., 2010. Open source learning management systems in e-learning and Moodle. In IEEE EDUCON 2010 Conference (pp. 593-600). IEEE.

Chang, V., 2016. Review and discussion: e-learning for academia and industry. International Journal of Information Management, 36(3), pp. 476-485.

Dumford, A. D., and Miller, A. L., 2018. Online learning in higher education: exploring advantages and disadvantages for engagement. Journal of Computing in Higher Education, 30(3), pp. 452-465. 
Gautam, S. S., and Tiwari, M. K., 2016. Components and benefits of e-learning system. International Research Journal of Computer Science (IRJCS), 3(1), pp. 14-17.

Gilbert, B., 2015. Online learning revealing the benefits and challenges. Education Masters. Paper 303, St. John Fisher College, New York.

Huang, Y. M., and Chiu, P. S., 2015. The effectiveness of a meaningful learning-based evaluation model for context-aware mobile learning. British Journal of Educational Technology, 46(2), pp. 437-447.

Islam, N., Beer, M., and Slack, F., 2015. E-learning challenges faced by academics in higher education. Journal of Education and Training Studies, 3(5), pp. 102-112.

Joshua, D., Obille, K., John, E., and Shuaibu, U., 2016. E-Learning platform system for the department of library and information science, Modibbo Adama University of Technology, Yola: A Developmental plan. Information Impact: Journal of Information and Knowledge Management, 7(1), pp. 51-69.

Kattoua, T., Al-Lozi, M., and Alrowwad, A. A., 2016. A review of literature on e-learning systems in higher education. International Journal of Business Management and Economic Research, 7(5), pp. 754-762.

Martínez-Caro, E., Cegarra-Navarro, J. G., and Cepeda-Carrión, G., 2015. An application of the performance-evaluation model for e-learning quality in higher education. Total Quality Management and Business Excellence, 26(5-6), 632647.

Muruthy, A. E., and Yamin, F. M., 2017. The perception and effectiveness of Learning Management System (LMS) usage among the Higher Education students. Journal of Technology and Operations Management, 12(1), 86-98.

Radu, F., Radu, V., and Croitoru, G., 2011, February. The advantage of the new technologies in learning. In: 10th international conference on artificial intelligence, knowledge engineering and data bases (pp. 150-155).

Rahrouh, M., Taleb, N., and Mohamed, E. A., 2018. Evaluating the usefulness of e-learning management system delivery in higher education. International Journal of Economics and Business Research, 16(2), pp. 162-181.

Rashid, Z. A., Kadiman, S., Zulkifli, Z., Selamat, J., and Hashim, M. H. M., 2016. Review of web-based learning in TVET: history, advantages and disadvantages. International Journal of Vocational Education and Training Research, 2(2), p. 7.

Raspopovic, M., Cvetanovic, S., and Jankulovic, A., 2016. Challenges of transitioning to e-learning system with learning objects capabilities. The International Review of Research in Open and Distributed Learning, 17(1). https://doi.org/10.19173/irrodl.v17i1.2172

Raspopovic, M., Cvetanovic, S., Medan, I., and Ljubojevic, D., 2017. The effects of integrating social learning environment with online learning. The International Review of Research in Open and Distributed Learning, 18(1), pp. 141-160.

Rusu, B., and Tudose, M. B. 2018. Quantitative analysis of main advantages and disadvantages of the use of e-learning in a technical University. In: The International Scientific Conference eLearning and Software for Education, (Vol. 4, pp. 224-231), Romania.

Salloum, S. A., and Al-Emran, M., 2018. Factors affecting the adoption of e-payment systems by university students: extending the TAM with trust. International Journal of Electronic Business, 14(4), 371-390.

Salloum, S. A., Al-Emran, M., Khalaf, R., Habes, M., and Shaalan, K., 2019. An innovative study of e-payment systems adoption in Higher Education: theoretical constructs and empirical analysis. International Journal of Interactive Mobile Technologies (iJIM), 13(06), pp. 68-83.

Samsuri, N. N., Nadzri, F. A., and Rom, K. B. M., 2014. A Study on the student's perspective on the effectiveness of using elearning. Procedia-Social and Behavioural Sciences, 123, pp. 139-144.

Sarkar, S,. 2012. The role of information and communication technology (ICT) in higher education for the 21st century. Science, 1(1), pp. 30-41.

Sarrab, M., Al-Shihi, H., and Rehman, O. M. H., 2013. Exploring major challenges and benefits of m-learning adoption. Current Journal of Applied Science and Technology, pp. 826-839.

Songkram, N., 2015. E-learning system in virtual learning environment to develop creative thinking for learners in higher education. Procedia-Social and Behavioural Sciences, 174, pp. 674-679.

Songkram, N., Khlaisang, J., Puthaseranee, B., and Likhitdamrongkiat, M., 2015. E-learning system to enhance cognitive skills for learners in higher education. Procedia-Social and Behavioral Sciences, 174, pp. 667-673.

Talebian, S., Mohammadi, H. M., and Rezvanfar, A., 2014. Information and communication technology (ICT) in higher education: advantages, disadvantages, conveniences and limitations of applying e-learning to agricultural students in Iran. Procedia-Social and Behavioral Sciences, 152, pp. 300-305

Yilmaz, R., 2017., Problems experienced in evaluating success and performance in distance education: A case study. Turkish Online Journal of Distance Education, 18(1), 39-51. 